\title{
Why the world is still unequal: On the apparatuses of justification and interpassivity
}

\author{
SCHALK ENGELBRECHT
}

\begin{abstract}
Inequality offends our moral sensibilities, yet there is no urgency to address it. This article explains the lack of an adequate response to inequality by outlining two apparatuses conspiring to perpetuate inequality - rational justification and interpassivity. The current state of inequality is bolstered by a variety of philosophical and economic rationalisations. However, even when these justifications fail, a system that maintains inequality survives through an ideological mechanism that allows collective delusions to be sustained without owners. Put differently, because others believe on our behalf, we can act in accordance with failed assumptions. To address inequality requires addressing these apparatuses.
\end{abstract}

Keywords: inequality, interpassivity, moral impulse, John Caputo, Slavoj Žižek

\section{INTRODUCTION: EQUALITY FOR INEQUALITY'S SAKE}

Equality is not pursued for its own sake. Promoting equality, and denouncing a state of inequality, serves two greater and more prized forms of inequality - one that we clumsily call 'ethics', and another that we awkwardly call 'individualism'. Put differently, inequality is the most urgent of moral concerns in society, but one which we are yet to address seriously. To address economic inequality would therefore mean to finally start meeting our infinite moral obligations towards others (to heed the call of that asymmetrical relationship with others, called 'ethics'). Addressing economic inequality also allows us to better invest our energies in the more fulfilling task of developing what is delightful in us, of 'expressing a personality', of becoming unequal in a way that neither invites scorn, nor causes ill conscience, i.e. to allow everyone to experiment existentially (to express individuality), not only those who are accidentally privileged enough to do so.

As things stand, unfortunately, economic rationality trumps ethics (or the moral impulse to address inequality), and inequality thwarts the work of personality. Consequently, we do not even try to meet our moral obligations, and the task of self-creation is near impossible for most people. These tasks (the ethical and

\author{
Schalk Willem Petrus Engelbrecht \\ KPMG Forensic \\ KPMG Wanooka Place \\ 1 Albany Road \\ Parktown \\ Johannesburg \\ 2193 \\ South Africa \\ T: +27827137656 \\ E: Schalk.Engelbrecht@kpmg.co.za
}

Schalk Engelbrecht is the head of Ethics Advisory within KPMG South Africa's Forensic Business Unit and a research fellow at Stellenbosch University's Centre for Applied Ethics. Before joining KPMG, Schalk lectured philosophy and ethics at Stellenbosch University and the University of North-West (Potchefstroom). He completed his PhD in philosophy at Stellenbosch University with a dissertation on the possibility of reviving utopian thought in an anti-utopian age. 
the existential) are delayed in contemporary society, and will remain delayed until academics, politicians, and practitioners have proven themselves equal, at least, to the task.

This, then, is the focus of this article: the question, What is the task to which we must be equal? To address this question, I will consider a set of related questions, including:

- What part of inequality irritates our moral sensibilities?

- How is this form of inequality rationalised?

- What is the price of inequality and its rationalisations? and

- What prevents us from addressing it?

I will argue that inequality, together with its resultant individual and social costs, is sustained through an apparatus of justification. The economic system of free market capitalism is built on a misleading and counterproductive philosophical edifice. But even when cracks in the foundation become apparent, our participation in the system is not threatened. To understand why, and why no real attempt is made to address inequality, the contemporary workings of ideology are explained with reference to the work of Slavoj Žižek (1989; 2012), and to the concept of 'interpassivity'. In short, the economic common sense of free market capitalism does not require our belief or allegiance. We can act as if we believe 'the system' works because others believe on our behalf. In order to (finally) address inequality, therefore, the rationalisations of inequality must continually be undermined, and new bases for interpassivity must be explored.

\section{THE INEQUALITY THAT OFFENDS}

Of course, not all inequalities are equal. Some inequalities are desirable. The inequality that offends morality - inequality understood as a general societal failure and a general moral imperative - is of a specific kind. To describe it, one can offer three qualifications.
First, the inequality that offends in this age is economic. Although we still identify previously unarticulated forms of political inequality, and although we remain concerned with the unequal treatment of women (for instance) in large parts of the world, the more pressing issue today is not political inequality. It is not the denial of rights and freedoms and vast inequalities before the law. Instead, it is the unequal distribution of the means of economic exchange and material security. Not because all necessary political rights have been articulated or addressed, but because the dilemma of economic inequality has repeatedly been articulated unsuccessfully. The iteration of the problem has never translated into an urgent moral imperative. Contemporary society makes no real effort to end economic inequality of the kind I describe here. The implications of this failure are felt, inevitably, in the realm of (political) freedoms.

A second, fairly obvious point is that the inequality that offends is a judgement concerning a certain relationship. Inequality is not an absolute measure, but a relative one. What concerns us, on the face of it, is neither abundance nor scarcity, neither plenty nor want. Instead, what raises ethical concerns is the co-existence of abundance and scarcity. If want were generalised, it would be tragic, but not an object of moral concern (unless, of course, the state of general scarcity were avoidable). Similarly, if the human condition were universally characterised by material excess, we might mourn the loss of 'spirit' that accompanied the struggle for existence, but we would not denounce the animal that resulted from this condition for the condition.

The third qualification is that economic inequality itself is not what sparks the moral impulse. We may be envious of those who have more than us, but we do not rebel against a situation in which it is possible for some to have more than others, materially speaking. While the contentment of the affluent is hateful to us, it is hateful in a way that is appealing enough to act as the object of consumption, of enjoyment even. Therefore, it is the lower end on the scale 
of inequality that demands moral intervention - that some have so little that they suffer, or that their humanity is diminished by it, while there seems to be ample material to go around. Inevitably, however, addressing the lower end of the scale of inequality entails a change in thinking that must affect how we view the upper end of the scale.

Inequality as a moral concern can therefore be described as the condition that unnecessarily allows for the distribution of exchange capacity and material security in such a way that some individuals suffer and are unable to attain, 'the good life'.

At this stage, it is important to address a possible objection. Economists would convince us that inequality and poverty (which I appear to conflate here) are two separate issues. Poverty, we are told, refers to "falling below a certain level of income" (Taylor, 2012:98). Inequality, on the other hand, refers to "the gap between those with low and high income" (Taylor, 2012:98). These phenomena are not directly correlated. Poverty rates may fall as inequality rises (when a strong economy helps poor citizens to get slightly richer, while the rich get much richer). Alternatively, inequality could fall while the poverty rate rises (when economic collapses bring many of the rich closer to the poor). Finally, poverty and inequality raise different moral concerns. When we take issue with poverty, it is out of sympathy for those without the means to enjoy basic necessities. When we take issue with inequality, we are motivated by ideas of fairness or justice.

Yet, today, poverty and inequality cannot be treated separately. Treating them separately is what allows morally indefensible inequality to continue. These phenomena cannot be separated, because 'more inequality' is offered as the solution to existing inequality. Additionally, the extent of existing inequality testifies of (global) productive capacity sufficient to provide for the needs of the many, yet is unflinchingly focused on the needs of few. This is the old and still valid Marxist argument that capitalism has served its historical function of developing the means of production to such a level that poverty and hunger can be eliminated. Yet, we maintain and defend arrangements that ensure that only the needs of some are met, and in such a way that waste is a necessary part of the arrangement.

\section{THE MORAL RESPONSE TO INEQUALITY}

That economic inequality, as I have described it above, calls for a response needs no rational defence. The moral impulse (even if its manifestations and associated attitudes, beliefs, and practices must be historically understood) reacts to it spontaneously. Before we can articulate objections to inequality framed in terms of justice, the common good, equality, intrinsic value, or fundamental rights, the experience of inequality has already elicited a moral response, a sense of 'wrongness', an immediate intuition that something must be done.

The work of John Caputo (1993) usefully and poetically describes the felt response that constitutes the ethical experience. According to Caputo, we do not reason ourselves into an obligation towards 'the Other'. The obligation is there before we start talking about it, and it binds or haunts us, even after we stop talking or acting:

To say that obligations 'happen' is to say that obligation is not anything that I have brought about, not anything I have negotiated, but rather something that happens to me. Obligations do not ask for my consent. Obligation is not like a contract I have signed after having had a chance first to review it carefully and to have consulted my lawyer. It is not anything I have agreed to be a party to. It binds me. (Caputo, 1993:7)

According to Caputo (1993), therefore, moral theory does not establish or even motivate the ethical relation. Moral theory is added retrospectively, to justify and explain logically what it is we experience: 
Obligation calls, and it calls for justice, but the caller in the call is not identifiable, decidable. I cannot make it out. I cannot say that the call is the voice of God, or of Pure Practical Reason, or of a social contract 'we' have all signed, or a trace of the form of the Good stirring in our souls or the trace of the Most High. I do not deny that these very beautiful hypotheses of ethics would make obligation safe, but my impiety is that I do not believe that obligation is safe. (Caputo, 1993:15)

If it seems necessary to bolster the moral impulse with argumentation denouncing inequality, then it is because so much rational effort has been expended in delegating or even abdicating responsibility in the face of economic inequality. In fact, one of the reasons why inequality is allowed to continue unabated is the hypocritical repression of ethics through rational justification. This, according to George Monbiot (2014), is one of the many good points Thomas Pikkety (2014) highlights in his book Capital in the Twenty First Century. "Extreme inequality," so Monbiot paraphrases Pikkety, "can be sustained politically only through an 'apparatus of justification'. If voters can be persuaded that insane levels of inequality are sane, reasonable and even necessary, the concentration of income can keep growing."

Today, the moral impulse must square up against this 'apparatus of justification', against centuries of economic justification and obfuscation. ${ }^{1}$ Inequality is either useful, or it is unresolvable. Of this, there is metaphysical proof, as the Divine itself proclaimed "the poor will always be with us". In the match-up between the moral impulse and economic rationality, the moral impulse therefore seems poorly prepared. The felt sense of obligation has neither an identifiable origin, nor can it rely on metaphysical endorsement or

1 According to John Maynard Keynes, there is no end in sight for the morally ambivalent logic of capitalist society: "For at least another hundred years we must pretend to ourselves and to everyone that fair is foul and foul is fair; for foul is useful and fair is not" (Keynes, as quoted in Skidelsky \& Skidelsky, 2013:43). enforcement. The only option left, according to Caputo (1993:38), for those few still beholden to obligation in the face of inequality, is to act as "obligation's poet", to make the case for equality look as strong as possible, and "to make indifference look as bad as possible, as bad as it is".

This, perhaps, is the first task conferred on us by inequality, the first task we must be equal to: to act as poets of obligation, to re-describe inequality in the worst possible terms, and to re-describe equality in more poetic terms. It means articulating and then lampooning the rationalisations of inequality. It also means voicing inequality's discontents.

\section{RATIONALISATIONS OF INEQUALITY}

In its sophisticated forms, the rationalisation of inequality proposes that it is the result of fundamental economic and democratic freedoms. To address inequality in a systemic manner, to interfere in the workings of a free market, would constitute a form of control, says Milton Friedman (1970), and an infringement on individual liberty. If we value the principles of liberty and property, we cannot force from above the redistribution of accumulated property.

Robert Nozick (1974), adding an element of justice or merit to the defence from freedom, argues that whatever we have accumulated through just acquisition and transfer cannot be forcefully redistributed without compromising that supreme value of freedom. What is 'justly acquired', or what we are 'entitled' to, according to Nozick, is what we have earned or inherited. Taxing what is justly acquired for the purposes of promoting the welfare of others amounts to little else than forced labour, or forcing a person to work for the purposes of another.

The defence of inequality from the perspective of freedom therefore claims that inequality is the result of free choices in a free market. No one can be blamed for it, and addressing it 
would mean sacrificing the ultimate value of freedom. Aligned with this defence is the idea that, if no law was broken in attaining one's income or property, then it was 'justly' acquired - one 'earned' it through talent or merit.

In its less sophisticated forms, though parasitic on the above logic, the rationalisation of inequality allocates blame for poverty or inequality. If inequality is the result of talent, merit, and free choices in a free market, then poverty is equally so. Poverty is the fault of the poor. It is through poor economic decisions, either their own or those of their parents, that poor people find themselves in poverty - because they choose to have too many children, because they choose to squander their earnings, not on self-development, but on Freud's palliative substances, because they choose charity over exertion. This type of blame allocation sometimes extends into the postulate of a 'culture of poverty'.

Finally, inequality, whether the result of freedom or merit, is ironically justified as the solution to inequality. The opportunity to pursue selfinterest almost limitlessly, so the argument goes, is in everyone's best interest. This is the Faustian bargain contemporary society has struck with the help of economists. Skidelsky and Skidelsky (2013:43), in reviving the alternative economics of John Maynard Keynes (1973), describe this bargain as "[putting morality] in cold storage till abundance [is] achieved, for abundance [makes] possible a good life for all". The trick, explain the Skidelskys, was to dress up the vice of avarice as a virtue, now dubbed 'self-interest' Society can then utilise the 'natural self-interest' of individuals for the good of all. Hence, Adam Smith (1976) (or a selective reading of Adam Smith) postulates that unconstrained selfenrichment promotes general well-being in society by creating wealth and opportunities from which all benefit. By pursuing financial self-interest, free individuals unintentionally advance the general interest of society. A variation of this argument was prominent in the 2012 American electoral campaign, in which Mitt Romney (2012) promoted the idea that economic challenges are best addressed by facilitating the work of so-called 'job creators' - those who, through the pursuit of profit and wealth, create employment for others. To restore the embattled US economy, Romney argued, will require "[renewed] faith in the power of free people pursuing their dreams". Romney therefore combined the defences of inequality based on the notions of freedom and utility. Free people, pursuing self-interest, are more effective in achieving social equity than any good-intentioned redistributive measures, or any measures directly aimed at social justice.

To summarise, inequality's apparatus of justification consists, mainly, of three rationalisations: (1) inequality is the outcome of fundamental economic and democratic freedoms, (2) inequality of holdings is the result of differences in merit, talent, or skill, i.e. those who have more, have earned more, and (3) inequality (or the possibility of unequal wealth) serves society as a whole by capitalising on the by-products (wealth and opportunities) of self-interested behaviour.

\section{CHALLENGING INEQUALITY'S RATIONALISATIONS}

To combat the self-satisfied logic that rationalises inequality, to make inequality look 'as bad as possible, as bad as it is', its basic conclusions have often been challenged in a reasoned fashion. For instance, it has been argued that the "ultimate value" of freedom is not protected or promoted through the inequality resulting from free markets. Instead, the lack of exchange capacity and material security implied by inequality means that most individuals are not 'free'. Freedom of enterprise, considered independently, is not freedom at all, but "the liberty to work or to starve" (Marcuse, 1968:2). In this situation, there is no semblance of the kind of autonomy that allows individuals to choose their own ends, and to choose different means for achieving those ends. 
It has also been argued that the distribution of exchange capacity today is by no means the result of just accumulation and transfer. The simplest example is inheritance. Inheritance effectively nullifies the holy capitalist principles of distribution according to productivity, equal opportunity, and freedom (Haslett, 2004). Inheritance is exchange capacity or wealth gained without the need for productive activity. At the same time, inheritance distributes opportunities and freedom (or autonomy) unequally.

South Africa's mining industry provides an equally interesting, if more contentious and complex, illustration of the injustice of just accumulation and transfer. In a recent report, titled Demanding the impossible? Platinum mining profits and wage demands in context(2014), researchers suggest that mining executives and shareholders have, over time, seized an increasingly large share of the value created through mining activity. When large profits are achieved, executives and shareholders allocate the lion's share to themselves. When profits are dwindling, executives still earn bonuses, while labourers are told their wage demands are unachievable. Justice seems far removed from such a scenario. Labourers consent under threat of unemployment. When labourers suspend their consent during wage negotiations, their continued dissent comes at the risk of starvation. If justice relates to contracts freely consented to, there are serious doubts about the extent of freedom labour brings to the table. If, on the other hand, justice relates to a fair distribution (distribution according to input), then a disingenuous logic is required to present the current income distribution between those extracting minerals from the ground and those administering the process, as fair or based on significant and demonstrable differences in input.

These arguments suggest that talk of freedom and justice amid inequality is questionable at best. Instead, a less unequal society would represent a significant gain in both freedom and justice.
Finally, history has debunked the utilitarian argument that inequality benefits all. What this notion has given us, instead, is a Sisyphean infinite loop. We lower taxes, allowing more freedom for the privileged, and relax labour laws. Economic growth sees some accumulating quickly and extravagantly, while others improve their condition incrementally. At this stage, and inevitably, the boulder we have been inching up the hill rolls back, and rolls over the majority of those whose positions had only improved incrementally. At the bottom of the hill, however, we are told the plan is sound. Only our execution was flawed. The strategy must not change. The solution to the predicament remains support for job creators.

The main rationalisations of inequality are therefore fundamentally flawed. This is not a revelation, and I am not revealing these flaws spectacularly in this paper. The fallacies that riddle the apparatus of justification have been identified endlessly, not only by Marxists and radicals, but by prominent economists, including John Kenneth Galbraith (2004) (who labelled our current economic arrangements 'fraud'), Joseph Stiglitz, ${ }^{2}$ and Ha-Yoon Chang, ${ }^{3}$ But while these challenges demonstrate how deficient the rationalisations of inequality are, and emphasise the losses suffered by those on the wrong side of inequality, they do not point out what everyone (not only the poor) loses in the process. Two forms of loss can be added - the loss of individualism and the loss of democratic solidarity.

\section{THE PRICE OF INEQUALITY I: INDIVIDUALISM}

In his essay The soul of man under socialism, Oscar Wilde (1891) rejected inequality for its detrimental effect on our capacity to realise ourselves, for the way it blocks off individual possibilities:

2 See Stiglitz, J.E. 2012. The Price of Inequality. Great Britain: Allen Lane.

3 See Chang, H. 2010. 23 things they don't tell you about capitalism. London: Penguin Books. 
One's regret is that society should be constructed on such a basis that man has been forced into a groove in which he cannot freely develop what is wonderful, and fascinating, and delightful in him - in which, in fact, he misses the true pleasure and joy of living. He is also, under existing conditions, very insecure. (Wilde, 1891:5)

Wilde's concern is for individualism, or the opportunity for each person "to realise the perfection of what was in him, to his own incomparable gain, and to the incomparable and lasting gain of the whole world" (Wilde, 1891:1). This sort of individualism is, for Wilde, the "full development of Life to its highest mode of perfection". Those who achieve this kind of perfection Wilde (1891:2) labelled "the poets, the philosophers, the men of science, the men of culture - in a word, the real men, the men who have realised themselves, and in whom all Humanity gains a partial realisation".

It is important to note, however, that Wilde was not only bemoaning the inability of the poor to experience the joy of living. The unequal distribution of property, of capital, of exchange capacity, diminishes the affluent and the under-privileged equally. The poor are robbed, and " $[\mathrm{m}]$ isery and poverty are so absolutely degrading, and exercise such a paralysing effect over the nature of men, that no class is ever really conscious of its own suffering. They have to be told of it by other people, and they often entirely disbelieve them" (Wilde, 1891:4). However, the affluent are equally hampered by accumulation. The gains of the rich may counter-productively prevent the realisation of individualism. As Wilde (1891:5) ${ }^{4}$ explained,

4 Wilde's argument is accurate in the way that it depicts the existential costs of inequality. However, it also contains a problematic metaphysical tone: individualism is described as realising something pre-existing within the individual. This metaphysics is secondary, however, and if one replaced Wilde's metaphysical individualism with a more Rortyan postmetaphysical conception of "selfcreation" - an ironic experimentation with
... the recognition of private property has really harmed Individualism, and obscured it, by confusing a man with what he possesses. It has led Individualism entirely astray. It has made gain not growth its aim. So that man thought that the important thing was to have, and did not know that the important thing is to be. The true perfection of man lies, not in what man has, but in what man is.

Variations on Wilde's century-old logic emerge today from neo-Aristotelian philosophers like Edward Skidelsky (2013) and Michael Sandel (2010). While Skidelsky and Sandel emphasise the loss of 'the good life' in their respective writings, their articulations of the good life inevitably encompass elements of the individualism Wilde defends. Edward Skidelsky (in collaboration with his economist father Robert Skidelsky) calls this element of the good life 'personality'. By 'personality', the Skidelskys (2013:160) mean "the ability to frame and execute a plan of life reflective of one's tastes, temperament and conception of the good". The idea of personality also includes "an element of spontaneity, individualism and spirit". One of the prerequisites of personality is "a private space ... in which the individual is at liberty to unfurl". Without personality, they continue, we would not be human. Instead, we would resemble "a colony of intelligent social insects". However, without financial security, it is improbable that this kind of personality will develop. The luxury of personality is therefore not allotted to the poor. Inequality also presses heavily on those who have more, and, consequently, they are unable to "isolate [themselves], to keep [themselves] out of reach of the clamorous claims of others" (Wilde, 1891:1).

The price of inequality is therefore individualism, at both ends of the scale of inequality - the poor do not have the luxury (of time or resources or solitude) to develop personality; the affluent, on the other side, are too encumbered by

a variety of possible re-descriptions - then Wilde's explanation of the detrimental effects of inequality is still valid. 
the duties of property and the relentless and insatiable pursuit of wealth, and the business of consumption, to attend to personality.

\section{THE PRICE OF INEQUALITY II: SOLIDARITY}

If inequality comes at the price of solitude, individualism, and personality, its price (ironically) also includes communality. At the altar of inequality we also sacrifice the opportunity to interact with others who make up our community. The cost is not only communality, but also democracy, so prized by the rationalisers of inequality. As Michael Sandel (2010:266) explains:

Too great a gap between rich and poor undermines the solidarity that democratic citizenship requires ... As inequality deepens, rich and poor live increasingly separate lives. The affluent send their children to private schools (or to public schools in wealthy suburbs), leaving urban public schools to the children of families that have no alternative. A similar trend leads to the secession by the privileged from other public institutions and facilities. Private health clubs replace municipal recreation centers and swimming pools. Upscale residential communities hire private security guards and rely less on public police protection. A second or third car removes the need to rely on public transportation. And so on. The affluent secede from public places and services, leaving them to those who cannot afford anything else.

According to Sandel (2010:267), the result is that people from different walks of life no longer encounter one another. Apart from 'personality', an unequal world therefore withholds the opportunity to develop 'civic virtue'. "The hollowing out of the public realm," Sandel argues, "makes it difficult to cultivate the solidarity and sense of community on which democratic citizenship depends."

In a passage that echoes Sandel, the Skidelskys (2013) argue that, when inequality exceeds certain bounds, a sense of mutual respect (necessary for the good life) is lost, and with it, democratic society:

An elite that lives, plays and learns entirely separately from the general population will feel no bond of common citizenship with it. A more equal - not completely equal - distribution of wealth and income is a requirement for democratic solidarity. (Skidelsky \& Skidelsky, 2013:159)

Even though the hidden costs of inequality, individualism and democratic solidarity, may seem like opposite purposes, recent warnings against sending one's children to Ivy League universities successfully combine these purposes. Josua Rothman (2014), in reviewing the work of William Deresiewicz (2014), combines the costs as follows:

Better to go to a state school, where the student body is more socioeconomically diverse, or to a 'second-tier' liberal-arts college, where 'real educational values' persist, than to submit yourself or your child to the careerist 'machine' of élite higher education ... Americans work too much, think too much about work, and cultivate an air of competent yet maniacal busyness. (Rothman, 2014)

The point of authors like Rothman and Deresiewicz is that isolated schools of privilege have two disadvantages: (1) where a student body is not economically diverse, education is incomplete (i.e. the argument related to 'civic virtue'), and (2) the education of the affluent comes at the expense of individualism, as students graduate to a life dominated by maniacal careerism and busyness.

\section{INTERPASSIVITY: WHAT PREVENTS US FROM ADDRESSING INEQUALITY}

It should be clear at this stage that the moral impulse demands a response to inequality; that the rationalisations of inequality are defunct; and that inequality costs us freedom, justice, personality, and solidarity. A final question 
then remains: Why have we not addressed it? If the price is so exorbitant, and the potential benefits of increases in equality so laudable, why have we failed to act, and why do we keep failing daily?

The answer to this question does not necessarily lie in a lack of sympathy or fellow-feeling. Philosopher Richard Rorty (1998:167-168, 176) believes that moral progress requires an increase in sympathy. For us to attend to the needs of the poor and the costs and externalities of inequality, we need to re-describe ourselves in such a way that the Other of inequality is regarded as "someone like us". If our redescriptions are successful, moral behaviour towards the poor will become as spontaneous as looking out for our friends.

Of course, Rorty has a point. There are instances where people are capable of violence against, or indifference toward, one another, only because 'the Others' are not 'people like us'. In discussing the crisis in the Middle East, for instance, opposing parties, Jews and Muslims alike, dehumanise their opponents, calling one another 'animals'. There are those who similarly think of the poor as 'not sufficiently like us' to earn our respect and warrant moral urgency.

Bracketing the threat of reverting to a totalising ethics of 'the same', the problem with Rorty's solution is that many people already regard the poor as sufficiently 'the same'. Many people in contemporary society have a deep sympathy for, and anguish over, the problems of poverty, hunger, and inequality. Yet, their fellow-feeling does not translate into action.

The reason for our inaction must therefore lie somewhere else. It lies in yet another mechanism, more insidious that the apparatus of justification. It is an apparatus that allows us to act in accordance with the justifications of inequality, even when we do not believe these justifications. This apparatus can be called 'ideology' or 'interpassivity'.

For Slavoj Žižek (1989:28), ideology no longer means "they do not know, but they are doing it". We do not submit to neo-liberal economic justifications of inequality because we are duped by them. We do not suffer from a false consciousness that makes us act in a way that serves elite interests without knowing it. Instead, today, ideology means "they know very well what they are doing, but still, they are doing it". Today, ideology critique can no longer mean exposing the false assumptions we cling to. They have already been exposed. We do not actually believe them, and the act of unmasking can therefore have no real effect. Ideology today is 'enlightened false consciousness'.

Consequently, even though we know very well that our pursuit of financial self-interest will not solve inequality, and will not produce a generally wealthy utopia, we continue acting out the roles and routines associated with this mechanism as if it would work. We do this because ideology no longer requires individual belief or false consciousness. We can continue to act out our roles, because others believe for our part, or on our behalf.

This has also been called 'interpassivity' or the problem of "illusions without owners" (Pfaller, 2014:15). Interpassivity is an apparatus that relieves us of our duties when others act out these duties on our behalf. As Pfaller explains, the required "attitude or conviction is realized through ... external agents”. To explain how this apparatus works, Žižek (1989) uses various analogies, of which I will mention two.

The first analogy is that of the Tibetan prayer wheel. This apparatus allows the religious subject to pray without praying, because the wheel that is spun to execute the prayer does the work on the subject's behalf:

... the wheel itself is praying for me, instead of me - or, more precisely, I myself am praying through the medium of the wheel. The beauty of it is that in my psychological interior I can think about whatever I want, I can yield to the most dirty and obscene fantasies, and it does not matter because - to use a good old Stalinist expression - whatever I am thinking, objectively I am praying. (Žižek, 1989:34) 
Ideology is a similar apparatus. It allows us to dispense with the conviction, while persisting with the routines associated with the conviction.

The second analogy Žižek (2009:51) uses to explain the interpassive logic of ideology takes the form of an anecdote told of the physicist Niels Bohr. According to Žižek, the famous physicist Niels Bohr was once visited at his home by a friend. The friend was surprised to find a horseshoe mounted above Bohr's front door - a popular ornament in Europe, motivated by the superstition that such ornaments keep away evil spirits. When Bohr opened the door, his friend asked him about it: "Niels, do you believe in the superstition that horseshoes keep away evil spirits?" "Of course not," Bohr replied, "I'm a scientist, not an idiot." "Then why did you put it up?" the friend asked, to which Bohr replied, "I hear it works even if you don't believe in it."

Contemporary society's prayer wheel, its horseshoe, is economics (or, at least, free market economics). Economics is our interpassive response to inequality - that which allows inequality to go unattended. Economic theory, expert economists, and the whole apparatus surrounding the theory (reserve banks, the IMF, the World Bank, analysis by economists on the news, expectant predictions of the next decision regarding the repo rate) serve to assure us that the system prays or acts on our behalf, that someone believes the pursuit of financial self-interest and its ultimate goal of economic growth will finally relieve us of the plight of the poor, or is, at least, the best and only way to address this plight. We can spin the wheel and hang the horseshoe, and rest easy. The result: we continue working towards promotions or increases; we look for better-paying jobs; we save to buy the artefacts associated with our (or the next) standard of living; we condone extravagant executive pay (and even hope to be that executive one day); and we refrain from giving to the poor, for fear of becoming a handmaiden to idleness. No direct action to address inequality is required on our part. No urgency exists, because interpassive economic activity means we are already doing our part. For this reason, and because economics has convinced us that the insatiability promoted by our economic system needs no moral limit, the Skidelskys (2013:12) ${ }^{5}$ label it (the discipline of economics) "the chief intellectual barrier to realizing the good life for all”.

Challenging this 'deathly orthodoxy', the interpassive apparatus that maintains inequality, is rendered unthinkable through additional (strengthening) procedures, of which one is 'complexity'. The purpose of this procedure is to stave off systemic change. If the economy fails to deliver on its promises, then it is because it is so complex: "...uncontrollable forces have unpredictable consequences; for instance, the invisible hand of the market may lead to my failure and my neighbour's success, even if I work much harder and am much more intelligent" (Žižek, 2012:9-10). If the workings of this complex phenomenon are so opaque, however, this also serves as a warning not to

$5 \quad$ It is tempting here to illustrate the way in which economics deconstructs itself with reference to that seemingly innocent and unimportant phrase ceteris paribus. The economist must, through no fault of her own, provide us with half of justice, and therefore no justice whatsoever, for she must operate according to the simple ('necessary') principle ceteris paribus. It is always offered as a qualification, an (unnecessary) aside, and yet it is not what follows or precedes ceteris paribus that is the key message of economics. It is exactly ceteris paribus that the economist unknowingly evangelises, preaches, believes. In short, economics recognises, from the start, that its assumptions only work when 'all things are equal'. Self-interest will promote general wellbeing ... assuming all things are equal. In free markets, resources will be allocated to the most efficient units ... assuming all things are equal. These claims already assume that all people are equal to the extent that they are self-interested utility maximisers. Economics is therefore ideal for interpassive purposes. It displays no urgency for equality, because it already assumes all things equal. The result is that it remains at odds with justice, which requires the treatment of people as fundamentally different or unequal, phenomenologically speaking. 
meddle, to experiment, or even to attempt to understand the economy. Best to leave it to the experts, to spin the wheel and hope it favours you.

\section{CONCLUSION: THE TASKS OF INEQUALITY}

Given the situation I have sketched, in which the moral impulse is confounded, first through an apparatus of justification, and then through the apparatus of interpassive economics, with the resultant costs of freedom, justice, individualism and solidarity, inequality does seem to confer tasks on us.

First, as poets of obligation we must debunk and keep debunking the apparatus of justification, not because people are generally blind to its fallacious nature, but to rob interpassivity of its power by ensuring that its hypocrisy is repeated more often than its 'benefits'. The second dimension of our moral poetics is to articulate and re-articulate the costs of inequality.

The above poetics would be assisted by, and would flourish best within, a revived public realm. This can be achieved in two ways. First, as the Skidelskys (2013:86-95) and Sandel (2010:260-269) recommend, we should bring notions of 'the good life' back into the public fold. These notions serve to emphasise the costs of inequality, and they start introducing a limit to accumulation. Second, reviving the public realm also means reinvesting in public spaces. The value and dynamics of public spaces cannot be developed here, but has received increasing attention from, among others, David Harvey (2012). ${ }^{6}$ For our purposes, public spaces promote solidarity, but also slow interpellation into a consumerist, careerist, and interpassive routine, by allowing for interaction with those who embody alternatives.

Finally, the perpetuation of inequality is achieved through unconvincing routine, based

6 See, for instance, Harvey's arguments around urban commons in Rebel Cities (2012). on failed assumptions. Halting the process may therefore require basing new routines on new assumptions, even if we are equally unconvinced of the new assumptions and routines. For instance, instead of assuming insatiability, we can assume a point of material comfort that is sufficient for attaining 'the good life'. Instead of assuming that people are self-interested utility maximisers, we can allow for a variety of motivations that exceed material goods. Instead of assuming that economic growth will increase general welfare, we can accept that markets need assistance in allocating exchange capacity and material security. Instead of assuming that success in business is determined by profit and share price, we can establish social and ethical performance as the markers of success.

These new assumptions would require new routines. Routinely increasing executive pay would be replaced with the capping of executive pay. Routinely increasing advertising budgets would be replaced with limits to advertising. Routinely seeking tax breaks to encourage job creators would be replaced with increasing taxes - for the rich, but also on estates. Routinely having social and ethics committees reporting to audit committees would be replaced by audit and remuneration committees reporting the other way around. ${ }^{7}$ These new organisational routines may seem unthinkable. Yet, they have been advocated repeatedly by a set of vocally anti-neoliberal economists (including those mentioned in this article - Chang, Skildesky, Stiglitz, and Galbraith), who also emphasise that economics and the economy requires no particular expertise to change.

Working out the details of new economic routines is not my purpose here. Instead, my intention is to pinpoint a blockage in our moral plumbing. We may have a reservoir of moral energy, yet it fails to reach its destination. Put differently: we have a lot of water, but no water pressure.

7 For this idea, I am indebted to a colleague Gwendolyn Zorn. 
Unblocking the moral impulse is, unfortunately, not only a matter of debunking rationalisations of inequality. Nor can we attempt to have people 'own' their convictions and attitudes, instead of acting them out interpassively. Instead, we should try to act out new interpassive routines that do not deny the problem of inequality, but that aims to end it.

The problem of interpassivity resembles the ongoing question in utopian studies of whether society is changed by changing individuals, or by changing their environment. The suggestion of a change in routine represents a middle path. Changing routine means changing the individual and the environment simultaneously, by changing the way individuals relate to their environment.

Our proper aim should be to address inequality, finally, or, as Wilde (1891:1) would have it, to "to try and reconstruct society on such a basis that poverty will be impossible". However, if we take seriously the work of Emmanuel Levinas (1985) (the philosopher who elevated ethics to 'first philosophy'), this is not possible. Even if poverty (the inequality that makes people suffer) were structurally eliminated, we would not be able to say that we have met our obligations. This is because ethics itself is a form of (phenomenological) inequality - an asymmetric relationship (with 'the other') that is infinite. As Levinas (1985) puts it:

I am responsible for the Other without waiting for reciprocity, were I to die for it. Reciprocity is his affair. It is precisely insofar as the relationship between the Other and me is not reciprocal that I am subjection to the Other; and I am 'subject' essentially in this sense. It is I who support all. ... I am responsible for a total responsibility, which answers for all the others and for all in the others, even for their responsibility. The I always has one responsibility more than all the others. (Levinas, 1985:98-99)

Even if the elimination of economic inequality would not exhaust our moral obligation towards others, at least we could anticipate a novel, as yet unarticulated obligation to replace this same tired one.

\section{REFERENCES}

Bowman, A. \& Isaacs, G. 2014. Demanding the impossible: Platinum mining profits and wage demands in context. Research report by Wits Society, Work and Development Institute. [Online] Available: http:// www.wits.ac.za/swop [Accessed 26 September 2014].

Caputo, J. 1993. Against ethics: Contributions to a poetics of obligation with constant reference to deconstruction. Bloomington: Indiana University Press.

Deresiewicz, W. 2014. Don't send your kids to the Ivy League. New Republic, 21 July 2014.

Friedman, M. 1970. The social responsibility of business is to increase its profits. New York Times, 13 September 1970.

Galbraith, J. K. 2004. The economics of innocent fraud. New York: Houghton Mifflin Harcourt.

Haslett, D. W. 2004. Is inheritance justified? In W. Shaw \& V. Barry (Eds.), Moral Issues in Business. USA: Wadsworth, 140-147.

Keynes, J.M. 1973. The general theory of employment, interest and money. The collected writings of John Maynard Keynes, Vol. 7. Cambridge: Cambridge University Press.

Levinas, E. 1985. Ethics and infinity Conversations with Philippe Nemo. Pittsburgh, PA: Duquesne University Press.

Marcuse, H. 1968. One-dimensional man. Boston: Beacon Press.

Monbiot, G. 2014. The rich want us to believe their wealth is good for us. The Guardian, 29 July 2014.

Nozick, R. 1974. Anarchy, State, and Utopia. New York: Basic Books.

Pikkety, T. 2014. Capital in the twentyfirst century. Translated by Arthur Goldhammer. Cambridge: The Belknap Press of Harvard University press. 
Pfaller, R. 2014. On the pleasure principle in culture: Illusions without owners. New York: Verso.

Romney, M. 2012. TRANSCRIPT: Mitt Romney delivers speech on the economy. [Online] Available: http://foxnewsinsider. com/2012/10/26/transcript-mitt-romneydelivers-speech-on-the-economy. [Accessed 13 August 2014].

Rorty, R. 1998. Human rights, rationality and sentimentality. In Truth and progress, Cambridge: Cambridge University Press, 167-185.

Rothman, J. 2014. What college can't do. The New Yorker, 5 August 2014. [Online] Available: http://www.newyorker.com/ books/joshua-rothman/what-collegecant-do [Accessed: 26 September 2014].
Sandel. M. 2010. Fustice. England: Penguin Books. Skidelsky, R. \& Skidelsky, E. 2013. How much is enough? Great Britain: Penguin Books.

Smith, A. 1976. An inquiry into the nature and causes of the wealth of nations. Oxford: Clarendon Press.

Taylor, T. 2012. The instant economist. USA: Plume.

Wilde, O. 1891. The soul of man under socialism. [Online] Available: http://www.marxists. org [Accessed: 18 September 2012].

Žižek, S. 1989. The sublime object of ideology. New York: Verso.

Žižek, S. 2009. First as tragedy, then as farce. New York: Verso.

Žižek, S. 2012. Revolt of the salaried bourgeoisie. The New Proletariat, 34(20):9-10. 